Mountain against the Sea 
This page intentionally left blank 


\section{Mountain against the Sea}

Essays on Palestinian Society

and Culture

\section{Salim Tamari}

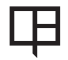

UNIVERSITY OF CALIFORNIA PRESS

Berkeley · Los Angeles . London 
University of California Press, one of the most distinguished university presses in the United States, enriches lives around the world by advancing scholarship in the humanities, social sciences, and natural sciences. Its activities are supported by the UC Press Foundation and by philanthropic contributions from individuals and institutions. For more information, visit www.ucpress.edu.

University of California Press

Berkeley and Los Angeles, California

University of California Press, Ltd.

London, England

(C) 2009 by The Regents of the University of California

Library of Congress Cataloging-in-Publication Data

Tamari, Salim.

Mountain against the Sea : essays on Palestinian society and culture / Salim Tamari.

p. $\mathrm{cm}$.

Includes bibliographical references and index.

ISBN: 978-0-520-25 I 29-8 (cloth : alk. paper)

I. Palestinian Arabs-Intellectual life-2oth cen-

tury. 2. Palestine-Social life and customs-2oth century. 3. Palestine-Civilization. I. Title.

DSII2.T36 2008

956.9405-dc22 2008021097

Manufactured in the United States of America
I7 I6 I5 I
4 I3 I2 II IO
0908
$\begin{array}{llllllllll}\text { IO } & 9 & 8 & 7 & 6 & 5 & 4 & 3 & 2 & \text { I }\end{array}$

This book is printed on Natures Book, which contains $50 \%$ post-consumer waste and meets the minimum requirements of ANSI/NISO Z39.48-I992 (R I997)

(Permanence of Paper). 
For Anton Shammas 
This page intentionally left blank 